\title{
O PERFIL DOS ESTUDANTES E A REALIDADE DO ENSINO DE LÍNGUA PORTUGUESA EM GUINÉ-BISSAU
}

\section{THE PROFILE OF THE STUDENTS AND THE REALITY OF PORTUGUESE LANGUAGE TEACHING IN GUINEA-BISSAU}

\author{
Imelson Ntchala Cá* \\ Cássio Florêncio Rubio**
}

\section{RESUMO}

Objetivamos, neste trabalho, investigar o perfil linguístico de estudantes guineenses e algumas características do material didático empregado para o ensino de língua portuguesa em Guiné-Bissau, com o intuito de estabelecer um comparativo entre as necessidades dos aprendentes e o que é ofertado para o aprendizado de português. Como subsídio teórico para discussão, consideramos, dentre outros, Almeida Filho (2005), Spinassé (2006), Carvalho (2011), Mendes (2011), Alves (2012), Sellan (2012) e Schoffen (2012). O corpus empregado na investigação é constituído de questionário aplicado a 50 estudantes guineenses do ensino superior da Universidade da Integração Internacional da Lusofonia Afro-Brasileira e de material didático de língua portuguesa empregado nas séries iniciais em Guiné-Bissau. Os resultados apontam diferentes fatores influenciadores da aprendizagem, como inadequação do material, idade de aquisição da língua portuguesa e procedimentos de ensino.

Palavras-chave: ensino de língua portuguesa; material didático; português guineense.

\section{ABSTRACT}

The objective of this study is to investigate the linguistic profile of Guinean students and some characteristics of the didactic material used to teach Portuguese in Guiné-Bissau, in order to establish a comparison between the needs of learners and what is offered for learning of Portuguese. As a theoretical subsidy for discussion we consider, among others, Almeida Filho (2005), Spinassé (2006), Carvalho (2011), Mendes (2011), Alves (2012), Sellan (2012) and Schoffen (2012). The corpus used in the research is a questionnaire applied to 50 Guinean students of higher education at the University of International Integration of Afro-Brazilian Lusophony and Portuguese-language didactic material used in the initial series in Guinea-Bissau. The results point to different factors that influence learning, such as inadequacy of the material, age of acquisition of the Portuguese language and teaching procedures.

Keywords: teaching of portuguese language; courseware; guinean portuguese.

\footnotetext{
* Universidade de Brasília (UnB), Brasília, DF, Brasil. imelsonntchalaca@yahoo.com.br

** Universidade da Integração Internacional da Lusofonia Afro-Brasileira (UNILAB), Redenção, CE, Brasil.cassiorubio@unilab.edu.br
} 


\section{INTRODUÇÃO}

A discussão proposta neste trabalho recai sobre a caracterização do material didático e dos procedimentos de ensino de português para os guineenses, um povo que, na sua grande maioria, teria o português como a segunda língua (L2). A população da Guiné-Bissau, conforme veremos adiante, ainda conserva as línguas de raízes (línguas étnicas), que estão bastante presentes nos contextos comunicativos informais. Isso sem considerar ainda a presença do guineense (também chamado de crioulo de Guiné-Bissau), uma língua bastante empregada na comunicação do dia a dia. ${ }^{1}$

Com base nessas questões, a proposta é investigarmos em mais detalhes quais seriam as necessidades dos estudantes guineenses relacionadas ao ensino/ aprendizagem de português e apontar algumas questões que provavelmente merecem ser levadas em consideração na elaboração do material didático de ensino da língua, dentre elas o perfil linguístico do estudante guineense.

Conforme será discutido, a elaboração do material didático e a prática do ensino do português devem levar em consideração o perfil social e linguístico dos estudantes. Essa perspectiva está presente em diferentes autores, como vemos nos trabalhos de Peixoto (2007), Ferreira (2012), Sellan (2012), Teixeira (2012) e Mendes (2011).

\section{FUNDAMENTAÇÃO TEÓRICA}

\subsection{Breve contextualização sócio-histórica da língua portuguesa na Guiné-Bissau}

De acordo com dados de Departamento de Assuntos Econômicos e Sociais das Nações Unidas, a população guineense atual é de 1.922.771. E, em conformidade com os dados de Instituto Nacional de Estatística da Guiné-Bissau (INE-GB), essa população está constituída por uma variedade de etnias, com línguas, estruturas sociais e costumes distintos, vivendo da agricultura e professando religiões locais. ${ }^{2}$

\footnotetext{
1. Ao longo de nossa discussão, optamos pelo rótulo "guineense" para nos referir à língua que se originou do contato de portugueses com guineenses, ainda que alguns autores optem pelo rótulo "crioulo". Consideramos essa denominação generalizante, por fazer referência a qualquer língua originada em situação de contato entre línguas, e inadequada, por sugerir que as línguas crioulas são simplificações de outras línguas.

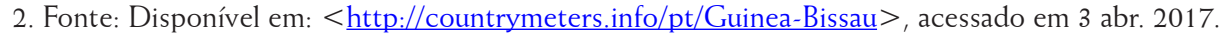


O país divide-se em oito regiões, nomeadamente: Bafatá, Biombo, Bolama/ Bijagós, Cacheu, Gabu, Oio, Quinara e Tombali e Setor Autónomo de Bissau. Essas regiões apresentam uma macroestrutura, por isso, são divididas nos seus respectivos setores. Sendo assim, temos 36 setores divididos administrativamente nas suas pequenas bases chamadas de secções, e essas secções são ramificadas em tabancas, chamadas também de aldeias. A taxa de alfabetização de todo o país é de cerca de $40 \%$, sendo o abandono escolar elevado por motivos econômicos, sociais e culturais (BENZINHO, ROSA, 2015). ${ }^{3}$

Benzinho e Rosa (2015) apontam que, na Guiné-Bissau, os primeiros vestígios da presença humana datam de 200 mil anos a.C., todavia os registros mais evidentes iniciam-se no terceiro milênio a.C., marcado pela chegada do povo do deserto do Sahara, ascendentes dos atuais grupos étnicos de litorais e ilhas da Guiné-Bissau.

A chegada dos portugueses e da língua portuguesa à Guiné-Bissau teria se dado entre 1445 e 1447 e foi atribuída a Nuno Tristão, que teria morrido numa dessas primeiras investidas, num ataque perpetrado pelas tribos locais no rio Geba. Outros historiadores atribuem a primeira chegada a Álvaro Fernandes que, pela mesma altura, teria chegado à praia de Varela.

As ocupações portuguesas seguintes, onde também se instalaram feitorias para fins comerciais, são posteriores a 1640 e foram sempre feitas a partir dos rios: Casamansa, São Domingos, Farim, Bissau, e, mais tarde, Bolama e Bafatá. Em 1753 é estabelecida pelos portugueses a Capitania de Bissau. Em 1879, procede-se à separação administrativa de Cabo Verde e constitui-se mais uma colônia de Portugal, a Guiné Portuguesa, que teve como primeira capital Bolama.

Após a Conferência de Berlim (1884-1885), em que Portugal apresentou o "Mapa Cor-de-Rosa", os portugueses apressaram-se a efetivar o povoamento da Guiné-Bissau e a dedicar-se à agricultura, não sem antes a população resistir e se travarem sanguinários combates. Em 1936, dá-se a última grande revolta, que ficou conhecida como a revolta dos Bijagós de Canhabaque. A população guineense foi então obrigada ao trabalho forçado, as infraestruturas poucas foram desenvolvidas e foi dada a preferência para a nomeação de cabo-verdianos como funcionários (BENZINHO; ROSA, 2015).

Em 1951, face à pressão internacional, o estatuto de Colônia da Guiné Portuguesa é substituído pelo da Província Ultramarina, mas a resistência guineense

3. Há divergência em relação aos valores exatos relacionados à população guineense, a depender dos autores e pesquisadores consultados. A mesma inexatidão se verifica quando consideramos as diferentes línguas faladas e seus percentuais de falantes. Isso ocorre porque ainda são escassos os estudos dessa natureza no país e porque não há números oficiais apresentados pelo governo. 
e a luta pela autodeterminação sempre se fizeram sentir, tendo como marco histórico a fundação do PAIGC (Partido Africano para a Independência da Guiné e Cabo Verde), em 19 de setembro de1956, por Amílcar Cabral, Luís Cabral, Aristides Pereira e Júlio de Almeida. Durante três anos a resistência do PAIGC foi pacífica, mas endureceu após o massacre do Pidgjiguiti, em 3 de agosto de 1959.

Em 1963, o PAIGC inicia a luta armada de guerrilha de oposição ao regime colonial, que fica registrada pelo assassinato do seu líder e doutrinário, Amílcar Cabral, a 20 de janeiro 1972, sem nunca se vir a determinar quem foi o responsável. A 24 de setembro de 1973, o PAIGC declara em Boé a independência unilateral da Guiné-Bissau, tornando-se a primeira das ex-colônias portuguesas em África a declarar-se independente. Portugal só reconheceu oficialmente a independência da República da Guiné-Bissau quando da deliberação da Assembleia Geral das Nações Unidas, a 17 de setembro de 1974 (BENZINHO; ROSA, 2015).

Basso e Gonçalves (2014) acrescentam que o movimento expansionista permitiu aos portugueses manter contato com realidades diversificadas nos âmbitos cultural e linguístico. Isso significa dizer que os portugueses e sua língua portuguesa encontraram outros povos, com suas próprias culturas e línguas. Essas línguas locais, com as quais o português teve contato, influenciaram também a língua portuguesa, sobretudo no que tange ao campo lexical, fato que levou à incorporação de inúmeras palavras originárias dessas línguas locais.

Sgundo o censo de 2009, último realizado no país, existem atualmente entre 27 e 40 grupos étnicos, e as etnias com maior expressão na Guiné-Bissau são: a Fula $(28,5 \%)$, que vive essencialmente no leste do país, em Gabu e Bafatá, seguida da etnia Balanta (22,5\% da população), que se encontra principalmente nas regiões sul (Catió) e norte (Oio); a Mandinga, com 14,7\%, no norte do país; a Papel, com 9,1\%, e a Manjaca com 8,3\%. Com expressão mais reduzida, encontramos ainda as etnias Beafada (3,5\%), Mancanha (3,1\%), Bijagó (que vive no Arquipélago dos Bijagós e representa $2,15 \%$ da população total), Felupe, com 1,7\%, Mansoanca $(1,4 \%)$ e Balanta Mane com 1\%. As etnias Nalu, Saracole e Sosso representam menos de 1\% da população guineense e 2,2\% assumem não pertencer a qualquer etnia (COUTO; EMBALÓ, 2010; PETTER, 2015; BENZINHO; ROSA, 2015, dentre outros).

As línguas nativas e o guineense hoje persistem e são faladas no cotidiano da população de Guiné-Bissau. Os líderes dos partidos de libertação nacional dos países africanos acolheram a língua portuguesa, fazendo dela uma língua de instituição e "instrução", ainda que os portugueses tivessem se retirado do território guineense.

Segundo Ferreira (1988), a oficialização do português deu-se por uma decisão dos líderes dos partidos da revolução de independência, respectivamente: o MPLA 
(Movimento Popular de Libertação de Angola), o FRELIMO (Frente de Libertação de Moçambique), o PAIGC (Partido Africano da Independência da Guiné e Cabo Verde) e o MLSTP (Movimento de Libertação de São Tomé e Príncipe), após a independência nacional de cada país.

Ainda na década de 1970, o crítico e sociolinguista italiano Guiuseppe Tavani escreveu um ensaio, denominado: "Problemas da expressão linguístico-literária nos países africanos de independência recente", no qual coloca em xeque a pertinência científica e ideológica de atribuir à língua portuguesa status privilegiado diante das outras línguas locais. ${ }^{4}$ Para Tavani (1975), ao se expressarem na língua do colonizador, os grupos africanos deixariam de transmitir as experiências originais e autônomas de sua realidade, permitindo, em última instância, fragmentos descontextualizados dessas experiências.

Uma outra questão relevante se colocava, no entanto, com relação à não elevação do português a principal língua, pois não havia como determinar, entre as inúmeras línguas locais, uma língua oficial, principalmente em Guiné-Bissau, onde as línguas locais estavam e estão vinculadas às diferentes etnias. Escolher a língua de uma etnia seria exaltar o povo dessa língua. Em relação à discussão, vale retomar as palavras atribuídas a Amílcar Cabral e divulgadas por Manuel Ferreira (1988, p.18-19):

O colonialismo não tem só coisas que não prestam; temos que ter um sentido real da nossa cultura. Pois o português, como língua, é uma das melhores coisas que os tugas (Portugueses), nos deixaram, porque a língua não é prova de nada mais senão um instrumento para os homens se relacionarem uns com os outros, é um instrumento, um meio para falar, para exprimir as realidades da vida e do mundo.

As palavras do líder e herói de luta nacional pela independência de GuinéBissau mostram o interesse e o elevado status que se confere à língua portuguesa na Guiné-Bissau desde muito tempo. Cabral via a língua portuguesa como uma virtude e um legado dos portugueses, como uma riqueza a ser aproveitada. Essa postura certamente contribui para a concretização do status de prestígio dado ao português, embora não seja o único fator determinante para tal efeito.

De acordo com Ferreira (1988), a concessão à língua portuguesa do status de língua oficial na Guiné-Bissau deve-se fundamentalmente às diversas situações, sejam de ordem social, política ou natural, sentidas e vividas desde o tempo da luta armada pela independência. Destacamos, dentre elas, as seguintes: a propaganda política, inúmeros textos de "esclarecimento e convencimento", programas da

4. Disponível em: <http://memoria-africa.ua.pt/Catalog/ShowRecord.aspx?MFN=41109>. Acesso em: 3 abr. 2017. 
rádio; a expressão no seio do exército, da administração, da igreja; a prática da escolarização nas zonas libertadas, constituindo-se assim espaços tomados pela língua portuguesa, a serem aprofundados logo depois de independência.

Outra situação diz respeito à complexidade linguística em que se encontra a República da Guiné-Bissau, já mencionada anteriormente. No solo guineense, não existe apenas uma língua como alternativa, existem muitas outras, variando de etnias para etnias.

Ferreira (1988) ainda acrescenta que a outra situação relevante é a péssima condição econômica na qual o país se encontrava depois de luta armada, já que havia saído de um conflito militar e economicamente não estava bem, não havendo, portanto, condições básicas para criação e organização das línguas locais, ou seja, mesmo que se escolhesse uma língua nacional, não havia condições mínimas para estruturação dessa mesma língua ao ponto de estar sólida e passível de ser ensinada nas escolas. Faltariam "textos, obras de apoio, gramáticas, dicionários, material didático, princípio de transcrição de léxicos de base, escolas apropriadas, professores e, de modo geral, condições mínimas e necessárias" (1988, p. 26-27).

Entretanto, de acordo com Peixoto e Carioca (2013), o português na GuinéBissau assume um status de língua oficial (LO) e serve apenas como língua da diplomacia. Cruz (2013, p. 39) argumenta que o conceito de língua oficial é nada mais que "um status que deriva duma decisão política abraçada com a astúcia na preponderância da educação, sendo língua de sapiência e cultura". Sendo assim, a língua portuguesa é simplesmente uma língua de prestígio e proporciona o reconhecimento social associado à sua condição de língua do conhecimento e da cultura.

Ferreira (1988) aponta que os Países Africanos de Língua Oficial Portuguesa (PALOP) têm desencadeado um grande esforço para o ensino da língua portuguesa no ambiente escolar. Trata-se de ensino do português planejado - com planos previamente elaborados e metas a alcançar - com a instituição de rede escolar de professores. A elaboração dos manuais é feita com o intuito de garantir um ensino de língua portuguesa sólido e eficaz, porém, com todo esforço feito pelos governos desses cinco países, as dificuldades e deficiências ainda persistem e são sentidas nas diferentes etapas de ensino.

O português é usado, em Guiné-Bissau, em situações e assuntos formais, empregado pelo governo nos atos de grande envergadura e na elaboração dos documentos oficiais, falado por uma pequena parte da população, perfazendo, nas estatísticas mais animadoras, o corresponde a $13 \%$ dos guineenses (COUTO, EMBALÓ, 2010). 
Além do português, de acordo com Couto e Embaló (2010), em GuinéBissau, existem por volta de 20 línguas faladas, muitas delas pertencendo a famílias diferentes. Dentre essas línguas, segundo os autores, podem-se destacar as seguintes: guineense (crioulo guineense), com $80 \%$ de falantes na população total do país; fula, com 16\% de falantes; balanta, ocupando a terceira colocação, com $14 \%$ de falantes; mandiga, com $7 \%$; manjaco, com $5 \%$; pepel, com $3 \%$, felupe, com $1 \%$; beafada, com $0,7 \%$; bijago, com $0,5 \%$, mancanha, $0,3 \%$; e nalu, $0,1 \%$.

Essas línguas étnicas assumem grande protagonismo no convívio e na comunicação do dia a dia dentro das famílias e na sociedade em geral, por isso são mais conhecidas, ao passo que o bayote, banhum, badyara ou pajadinga, cobiana, cumante, cassanca são consideradas menos faladas e conhecidas, porque atualmente já não têm percentagens expressivas de falantes. Há ainda outras línguas no país, como o wolof, o francês e o inglês, resultado de relações entre os guineenses e os povos de Senegal e Guiné-Conacry, países vizinhos, conforme apontam Couto e Embaló (2010).

O guineense, língua mais falada no país, surgiu do contato entre os portugueses e os povos guineenses, tendo como base o léxico português. A língua surge então, nesse contexto, para facilitar e estabelecer a comunicação entre europeus e africanos da região, mas também, de um largo modo, entre os africanos. (MOREIRA, 2006).

\subsection{Os conceitos de língua materna, segunda língua, língua oficial e língua estrangeira}

No decorrer de nossa discussão, empregamos alguns termos ou conceitos que precisam ser discutidos e aprofundados. Mencionamos, sobretudo, os termos língua materna (LM) e língua oficial (LO), mas é relevante estender esses conceitos, abrangendo também os conceitos da segunda língua (L2) e língua estrangeira (LE), que se encontram intimamente relacionados e, conforme aponta Bento (2013), a distinção entre eles tem gerado muitas discussões entre os investigadores, sobretudo nos estudos de linguística aplicada.

De acordo com Gass e Selinker (2008 apud BENTO, 2013), a língua materna (LM) é a primeira língua adquirida ou assimilada, e, por meio dela, o sujeito se expressa de forma natural, compreendendo o meio envolvente. E, além de ser o primeiro sistema linguístico de socialização da criança, adquirido em contexto familiar, constitui elemento fundamental de identidade e viabiliza ao indivíduo um sentido de pertença a um determinado contexto cultural e social. 
Bento (2013) destaca ainda que o exato momento de aprimoramento, amadurecimento e desenvolvimento de uma consciência dessa língua pode coincidir com o exato momento de aprendizagem de outras línguas não maternas.

Spinassé (2006) defende ainda que a língua materna (LM) não é, necessariamente, a língua da mãe, mas sim, fundamentalmente, a primeira língua com a qual a criança teve contato e aprendeu em casa, com os pais ou responsáveis. Essa mesma língua deve ser a língua da comunidade em que a criança está inserida. A LM é a língua que o falante estabelece ou com a qual está, sem necessidade de ir a escolas ou instituições oficiais de ensino. A LM é adquirida, independente do grau de escolaridade, ou seja, é uma capacidade do ser humano de adquirir a língua com a qual está em contato desde o momento do nascimento: língua dos pais, da família, da sociedade em que vive ${ }^{5}$. Da LM, o falante internalizará a gramática e será capaz de comunicar-se mesmo que nunca a tenha estudado (CARVALHO, 2011).

E, como defende Almeida Filho (2005), LM é a língua aprendida pela criança no ambiente doméstico, na rua, e é a língua de maior comunicação para esse sujeito desde casa aos demais lugares, inclusive na sociedade. Essa língua contribui, primordialmente, para a constituição da identidade pessoal, regional, étnica e cultural de uma pessoa, ainda que outras línguas com as quais o falante tem contato também contribuam na formação dessa identidade.

Toda LM se manifesta por meio de uma variedade linguística (uma variedade regional, muitas vezes combinada com traços étnicos e de classe social). Ora, pode acontecer de a criança ter aprendido outra língua que não a dos pais, por exemplo, a língua de comunidade; nesse caso, a criança será bilíngue e as duas línguas serão consideradas (LM/L1). O mesmo bilinguismo pode ocorrer quando membros da própria família falam línguas diferentes - observando que o domínio de ambas as línguas não é precisamente o mesmo.

Sendo assim, sabemos que, no contexto guineense, o meio cultural está de certa forma atrelado à ideia de que o indivíduo se relaciona a um grupo étnicocultural, principalmente na realidade daquele país, pois, segundo Benzinho e Rosa (2015), somente 2,2\% da população afirma não ser de etnia alguma. Por consequência, quase 98\% dos guineenses pertencem a uma etnia e essa está atrelada à sua respectiva língua étnica, que seria a língua materna para grande parte dessas pessoas, a depender, certamente, da presença, no seio familiar do guineense, de outra língua também apontada como materna.

5. À exceção de casos de falantes que ou não têm acesso a línguas (em função de isolamento, condições adversas) ou apresentam algum distúrbio/patologia que impede ou dificulta a aquisição de linguagem. 
Quanto ao conceito de segunda língua (L2), em conformidade com o que aponta Leiria (1999), o termo é aplicado para classificar a aprendizagem e uso de uma língua que não é nativa dentro de fronteiras territoriais, mas que tem um status ou função reconhecida dentro desse país. Segundo o autor, essa segunda língua (L2) é frequentemente uma das línguas oficiais, é eminentemente importante para a participação na vida política e econômica do estado, é a língua ou uma das línguas da escola, é uma língua do país e tem determinadas características que a diferem das outras línguas ou variedades nacionais ou regionais, e essas características são sentidas no discurso do falante não nativo.

Conforme destaca Bento (2013), a L2 é a língua que, normalmente, possui algum relevo na comunidade dos aprendentes, podendo ser reconhecida como língua oficial ou co-oficial e ser detentora de um status definido, sendo, por vezes, também língua de escolarização. Souto, Além e Gonzales (2014) acrescentam que a L2 pode se configurar na língua que também é falada no país ou na cidade como oficial. É o caso do guarani, no Paraguai, que não é uma língua muito utilizada pela sociedade em contextos mais formais, sendo empregada, nesses casos, a língua espanhola. Em Guiné-Bissau, de acordo com as definições dos termos LM e L2, propostas em Carvalho (2011), podemos inferir que, para a maioria da população, o guineense ou uma das línguas étnicas seria a LM, cabendo ao português o rótulo de L2.

Com relação à língua estrangeira, Souto, Além e Gonzales (2014) afirmam que esta seria uma língua ou idioma que não tem qualquer status sociopolítico num determinado local. Brumfit e Roberts (1983 apud ALMEIDA FILHO; CUNHA, 2007) acrescentam que o termo língua estrangeira é somente aplicado às línguas faladas fora das fronteiras do país. A língua estrangeira é aquela aprendida somente para comunicação com aqueles que vivem fora da comunidade de fala de alguém e não é usada na comunicação cotidiana dos membros dessa comunidade.

Leiria (1999) afirma que o aprendizado de uma língua estrangeira, dentre outros fatores, deve-se à curiosidade do sujeito, que aprende essa língua para saber ler os textos literários ou científicos, comunicar com habitantes de países que se queira visitar, sem que essa língua possua um status oficial nos países onde é aprendida e sem que seja indispensável para integração e relação dos seres humanos.

Por fim, a língua oficial, segundo Carvalho (2011), é aquela que os órgãos públicos utilizam em suas relações nas instituições do Estado. É a língua oficial que deve ser ensinada nas escolas e à qual todos os falantes devem ter acesso para uso em situações oficiais. Severo (2013, p. 455) aponta que "a natureza das regras que definem o status e o prestígio das línguas não é neutra/científica, mas 
política, uma vez que os processos de designação e de circulação das línguas instauram e conservam hierarquias". Sendo assim, a determinação de uma língua como oficial acarreta a legitimação de algumas línguas e o apagamento de outras e, por consequência, a legitimação de determinados grupos em detrimento de outros. Guimarães (2007), por sua vez, destaca que a língua oficial é a língua do Estado, de modo que as pessoas que estão ligadas a esse Estado são teoricamente consideradas falantes dessa língua.

A observação preliminar dos materiais didáticos empregados no ensino de língua portuguesa nas escolas públicas também sugere que a população guineense é considerada, hipoteticamente, pelo Estado, falante da língua portuguesa como LM. A priori, a população é considerada falante da língua portuguesa pelo fato de estar vinculada ao Estado que tem a língua portuguesa como língua oficial. Entretanto, muitas vezes, como argumenta Cruz (2013), a língua oficial é meramente um status aplicado a uma língua e decorrente de uma decisão política.

É importante salientar que falar de língua portuguesa como língua terceira para o contexto guineense não quer dizer que ela seja língua estrangeira, pois, para Souto, Além e Gonzales (2014), pode ser considerada terceira língua qualquer língua aprendida por um indivíduo depois deste já ter aprendido outras duas línguas. Para a maioria dos guineenses, o português é aprendido depois de terem aprendido a sua língua étnica e o guineense. É nesse sentido que se considera a língua portuguesa uma terceira língua.

Em suma, o que se aponta aqui é que o português, em Guiné-Bissau, é a língua oficial, porque é a língua do Estado e da educação; e seria a segunda língua, podendo ser adquirida por falantes que já possuem como língua materna uma língua étnica e/ou o guineense. É esse status que buscamos comprovar com base na pesquisa realizada entre os jovens estudantes guineenses.

\subsection{0 ensino de língua no contexto do multilinguismo}

Retomando o que expusemos até aqui, compreendemos que a Guiné-Bissau comporta o contexto do multilinguismo, pois existe no país uma pluralidade linguística, com a persistência de muitas línguas nativas, além do português. Dentre essas línguas, encontramos as que chamamos de étnicas e a língua de "integração nacional", o guineense. O português é a língua oficial e do estado e temos ainda as chamadas línguas estrangeiras, como o inglês e francês, aprendidos, muitas vezes, com finalidades econômicas e comerciais. 
A discussão que trazemos à baila se relaciona com a consideração desse contexto multilíngue no ensino da língua portuguesa e, além disso, na produção de material didático no país.

Os pressupostos teóricos apontam que o material didático para o ensino da língua para falantes que já têm outras línguas e que estão dentro do contexto multilíngue deve ser específico, no sentido de considerar a realidade dos estudantes (ver, dentre outros, PEIXOTO, 2007; CARVALHO, 2011; FERREIRA, 2012; UETI, 2012; TEIXEIRA, 2012; SCHOFFEN, 2012; SOUZA，2015; MENDES, 2011; ALVES, 2012; SELLAM, 2012; ANTUNES, 2003).

Peixoto (2007) focaliza o processo de leitura na sala de aula, com a análise do material didático do Projovem e apontamento de um problema a respeito de qualidade desse material, propondo uma ênfase no planejamento da aula de leitura, a partir das atividades de compreensão do texto. A pesquisadora defende um planejamento de aula comunicativa e considera o material didático tão importante na sala de aula quanto o professor, ao ponto de o interlocutor dos alunos não ser somente o professor, mas também o autor do material didático.

Carvalho (2011) parte da mesma perspectiva, alegando que o material didático se constitui em importante ferramenta de auxílio ao ensino, atuando como suporte ao professor. Devido a essa relevância, foram criadas no Brasil leis e programas federais para a escolha e o uso desse material na sala de aula, como exemplo o Programa Nacional do Livro Didático (PNLD). É importante que o material do ensino da língua portuguesa para falantes que não têm essa língua como materna seja adequado ao contexto social e linguístico dos aprendentes. Dessa forma, o processo de elaboração do material didático deve levar em consideração o fato de que esses estudantes possuem outras línguas maternas, travando contato com o português pela primeira vez no ambiente de sala de aula.

Ferreira (2012) apresenta estudo relacionado à elaboração de material didático do ensino da língua portuguesa para falantes de outras línguas, enfatizando que esse material deve levar em consideração o perfil linguístico, social e político do sujeito que o empregará. Para construir o material didático, deve haver um espaço de preparação, através de oficinas com professores que trabalharão na área e com o material. Mesmo com transformações ocorridas através do contato com o português, é preciso preocupar-se em construir um processo de ensino que garanta respeito, valorização da cultura e dos saberes tradicionais. Para a pesquisadora, se o contexto linguístico do povo é bilíngue, então o ensino tem que ser também bilíngue. A política é conservar as línguas maternas sem desconsiderar a importância da língua portuguesa. 
Para Ueti (2012), a utilização do material didático nas aulas de língua portuguesa para os falantes de outras línguas é relevante e inquestionável, contudo deve-se observar variados condicionadores, como as características dos alunos e a boa apresentação dos conteúdos programáticos. É de igual modo importante o uso/ ensino dos gêneros discursivos nas aulas no ensino de português como língua não materna, pois esses são os verdadeiros objetos de ensino da língua.

Na perspectiva de Teixeira (2012), o material didático é um elemento fundamental para o ensino de línguas, pois não serve apenas como uma ferramenta de aquisição de conhecimento, método e hábito de trabalho e estudo, contribuindo, por vezes, para formar cidadãos que respeitam a construção de conhecimento baseado na preservação de valores culturais e cívicos, sem discriminação étnica, religiosa e social. Por essa razão, é importante que os materiais didáticos de língua portuguesa como L2, ou como língua estrangeira (LE), sejam alvos de análise e avaliação, de modo a potencializarem o desenvolvimento da competência da oralidade, da escrita, da leitura e do conhecimento explícito da língua.

É importante que existam critérios para nortear a elaboração do material didático, os quais não devem ser regidos apenas por princípios científicos e pedagógicos, mas também linguísticos, conceituais, de articulação e de adequação ao desenvolvimento de competências gerais, específicas e facilitadoras de uma integração na vida ativa de qualquer cidadão, informando adequadamente e de modo perceptível a faixa etária a que se destina, destacando sempre valores que se revelam a partir da não discriminação de etnias, culturas, religião, sexo e gênero e da ausência de propagandas ideológicas, religiosas e políticas. Ferreira (2012) acrescenta que o processo de elaboração desse material didático deve ser específico e obedecer aos seguintes parâmetros: contemplar os conhecimentos do povo em causa, em toda a sua heterogeneidade, e a produção de material que registra e organiza tais conhecimentos de forma escrita e bilíngue. Os professores, que posteriormente trabalharão com o material, devem receber formação por meio de oficinas de capacitação, sendo o processo de elaboração uma dessas capacitações. Também devem ser levadas em consideração outras áreas do saber, abordadas de forma interdisciplinar. $\mathrm{O}$ trabalho de ensino de português tem que partir da ideia de uma aprendizagem do português a partir do contexto cultural.

Conforme aponta Schoffen (2012), é importante o uso de materiais autênticos em sala de aulas de língua adicional, porque possibilita a reflexão sobre as condições de produção do uso de linguagem na interação social. A elaboração de materiais didáticos voltados ao ensino de uma língua adicional precisa dar contar das opções lexicais e sintáticas, expressões e gírias, fenômenos prosódicos, fazendo com os alunos reflitam sobre o uso da linguagem e sua relação cultural com a comunidade de fala na qual o texto 
circula, as aproximações e os distanciamentos existentes entre certos padrões estabelecidos na cultura do aluno e na cultura da língua alvo. Portanto, o material tem que ser acompanhado de tarefas orientadas por gêneros discursivos, em sala de aula e na cultura do aluno.

Ferreira (2012) acrescenta que, apesar de a tarefa de elaborar material didático para esse fim específico (já que a elaboração demanda a intervenção de muitas instâncias) ser difícil, ela é possível, desde que haja o auxílio de órgão competente e a participação ativa de todos os segmentos da comunidade. Segundo aponta Mendes (2011), existem autores que discutem a importância da seleção e da produção de materiais com uma forte preocupação com a organização prévia dos dados da língua, a categorização e a ordenação em sequências, mas, ao contrário de proporcionarem ao aprendiz um contato ou encontro significativo com a língua que está aprendendo, endurecem o seu aprendizado e tornam a língua menos acessível.

Os materiais devem preocupar-se em refletir e usar as estratégias dos aprendizes e os esquemas prévios que eles levam para sala de aulas, além de incentiválos a estabelecer um diálogo entre a sua língua-cultura e a língua-cultura que estão aprendendo. Nessa perspectiva, devem funcionar como suporte, apoio, fonte de recursos para que se construam, em sala de aula, ambientes propícios à criação de experiências na língua-alvo. Longe de obedecer à sequência rígida, à seleção ou à ordenação dos dados que não podem ser mudados, manipulados, explorados, o material deve ser adaptado, modificado, adequado a diferentes situações, de acordo com as percepções do professor enquanto aos desejos e necessidades dos alunos (MENDES, 2011).

Dentre as várias metodologias para o ensino de línguas não maternas, Alves (2012) aponta que a abordagem comunicativa é bastante empregada e a gramática já não constitui o centro de aprendizagem, nem tão pouco é suficiente para garantir e permitir interação em situações de comunicação. Sellan (2012) assegura que ensinar e aprender uma nova língua não deve se resumir ao conhecimento sobre o sistema da língua em estudo e é importante dar a atenção aos outros componentes, entre eles a aquisição da oralidade e da escrita, os usos de argumentos, os atos da fala, as condições de produção discursiva, a organização textual, seleção e emprego lexicais e as visões sócio-histórico-culturais. Todo esse procedimento viabiliza o interesse do aluno para aprender a nova língua. Na lógica de Sellan, a oralidade deve constituir um fundamento no ensino e aprendizagem da língua portuguesa como L2, mesmo que os aprendentes falem "errado", pois é indispensável aprender a dialogar, e isso pode acontecer a partir do que Piaget chama de interação social. 
Para Silveira (1988 apud SELLAN, 2012), ensinar/aprender outra língua não significa sobrepor a cultura da língua alvo a cultura de origem do aluno, mas, à medida que ele vai assimilando a cultura da nova língua, vai enriquecendo, simultaneamente, sua cultura e é levado a tomar consciência da sua própria identidade. De acordo com Schoffen (2012), há a necessidade de desenvolver o ensino de língua a partir da percepção do cotidiano e das ações realizadas no dia a dia dos locais, distanciandose de julgamentos de valores, mas, para que isso aconteça, é importante adotar um olhar que consiga ver determinada prática no contexto em que ocorre. A autora ainda acrescenta que o importante no ensino de língua adicional é focar em uma prática que leve os alunos a dar sentido aos fatos que eles mesmos descobriram no seu estudo da língua alvo:

O trabalho do ensino de língua tem que ser realizado a partir dos diferentes gêneros do discurso em que se realiza. Faz-se necessário que o ensino leve em consideração os gêneros dos discursos nos quais os textos utilizados em sala de aula estão inseridos e as relações culturais expressas através deles, pois isso viabiliza a reflexão sobre o uso da linguagem como algo social, a partir de materiais didáticos que levem em conta a relação dialógica da prática social e o contexto em que ela estabelece, e de que forma essa reflexão pode influenciar ou auxiliar os alunos na aprendizagem da língua na medida em que colabora para que eles relacionem sempre as formas linguísticas ao seu uso situado. (SCHOFFEN, 2012, p.24)

Com relação às tarefas propostas como plano norteador das ações dos participantes ou dos alunos, Schoffen (2012) aponta que as tarefas didáticas que se propõem trabalhar na perspectiva de gêneros do discurso estimulam e ajudam os alunos a assumirem, na sala de aula, a posição do falante. Uma vez na posição de interlocutor, o aluno vai interagir na língua que está aprendendo, nos seus diferentes contextos de uso. Para isso, a tarefa didática deve facultar aos alunos situações comunicativas evidentes, para que assim possam descobrir sua posição enunciativa.

Conforme aponta Mendes (2011), aprender uma língua como o português é aprender a estar socialmente em português, isto é, a usar a língua portuguesa no seu diverso modo e contexto, dado que sem o uso a língua não passa de uma abstração. Antunes (2003) acrescenta que a análise ou estudo de frases soltas, sem contextualização, inviabiliza o reconhecimento da dependência entre a linguagem e os seus contextos de uso, assim sendo é eminentemente importante o uso de textos reais para o ensino da língua.

Quanto aos equívocos cometidos pelos alunos durante o processo de ensino e aprendizagem de línguas adicionais, Gargallo (2004 apud ALVES, 2012) destaca que $30 \%$ a $50 \%$ acontecem por influência dos parâmetros da língua materna do falante e não devem constituir um problema. Esses equívocos possibilitam que o 
professor verifique em que medida os aprendentes progrediram na aprendizagem da língua de modo a adaptar, quando necessário, novas medidas de ensino, e ajudam o investigador oferecendo dados importantes sobre o processo de aprendizagem da língua. Enfim, os erros podem ser considerados uma estratégia à qual os aprendentes recorrem para testar as hipóteses acerca do funcionamento da L2/LE.

Para Alves (2012), a ocorrência e a identificação dos erros no processo de ensino e aprendizagem de uma nova língua é até benéfica, porquanto ajudam o professor a definir e redefinir novas estratégias de ensino e a produção de materiais didáticos adequados para salas de aulas. A autora acrescenta que esses erros interlínguas não são aleatórios, existindo uma forte motivação e sendo cometidos, quase sempre, em função do conhecimento das outras línguas.

Ensinar uma língua, portanto, é mais do que fazer os alunos conhecerem a nomenclatura dos elementos gramaticais, a sua estrutura, visto que ela vai além desses elementos, representa mais do que a fala, mais do que a estrutura, mais do que um instrumento para trocar as ideias e informações, ela é um símbolo, um modo de identificação, um sistema de produção de significados individuais, sociais, e culturais, uma lente através da qual enxergamos a realidade que nos circunda (MENDES, 2011).

Cabe acrescentar à discussão os fatores que influenciam o processo de ensino de língua para falantes de outra língua. De acordo com Nascimento e Santos (2013 apud SOUZA, 2015), os recentes estudos neurocientíficos apontam que a idade mais propícia para aprendizagem da segunda língua (L2) vai da infância até os cinco anos de vida, visto que é durante esse período que o desenvolvimento cerebral ocorre de maneira surpreendentemente acelerada. Para autores como Benfield e Roberts (1959 apud SOUZA, 2015), até os 9 anos de idade, essa plasticidade cerebral das crianças facilita a compreensão do input recebido. E Souza (2015) acrescenta ainda que, para a neurociência, a criança apresenta uma rede neural complexa, conectada a bilhões de "conexões sinápticas" que fazem com que haja uma larga facilidade para o aprendizado.

Entretanto, Vygotsky (1996 apud SOUZA, 2015) adverte que, ainda que a criança tenha toda essa capacidade e facilidade, é importante a adoção de programas pedagógicos que combinem com perfil e capacidade de apreensão do novo conhecimento que a criança está adquirindo, ou seja, a criança se encontra disponível e cheia de condições para aprender a nova língua, mas se os programas pedagógicos não forem bem estruturados, haverá dificuldade em adquirir novos conhecimentos e a nova língua. 
Além da idade, Souza (2015) destaca que a aprendizagem sólida e consistente de qualquer objeto de conhecimento dá-se a partir da interação, ou seja, é importante interagir com o objeto que queremos aprender, isso é fundamental. A criança possui a capacidade de adquirir de forma mais fácil um novo idioma, mas por meio da interação. $\mathrm{O}$ autor observa que o adulto apresenta mais esforços, dificuldades e desafios para aprender uma nova língua ou uma segunda língua, e já busca aprender a nova língua tendo em conta certa necessidade, ou seja, é condicionado a aprender a nova língua por um motivo que pode ser profissional, pessoal e até cultural, o que causaria mais dificuldades na aprendizagem de uma nova língua.

Schutz (2014, apud SOUZA, 2015) destaca ainda um outro fator: a forma como o cérebro desenvolve o que ele chama de lateralização. Assim, o fato de, na criança, esse processo ainda se encontrar em desenvolvimento vai garantir a percepção das variadas quantidades de sons e a sua internalização com facilidade. Já para os adultos, a situação é diferente e complexa, porque estão numa fase de vida em que a lateralização do cérebro já se encontra completa e bem desenvolvida. Esse amadurecimento faz que os adultos apresentem dificuldades em assimilar e reproduzir novos sons com facilidade.

Outro fator relevante que Schutz (2014, apud SOUZA, 2015) nos apresenta é a formação da matriz fonológica. Segundo esse autor, enquanto no adulto a consciência fonológica já está sedimentada, na criança essa matriz ainda está em formação, contribuindo para a aprendizagem da outra língua. $\mathrm{O}$ adulto vai ter mais dificuldades na reprodução de novos sons, uma vez que tenderá a utilizar como referência os sons de sua língua materna e, por essa razão, terá dificuldades em reproduzir um som muito distante daquele de sua matriz fonológica, gerando erros nesse aprendente (SOUZA, 2015).

O importante nessa questão não é definir com precisão o momento em que ocorre ou não ocorre o processo de aprendizagem da nova língua, não obstante é preciso mostrar que existem momentos em que o processo de aprendizagem ocorre com mais facilidade. Esse momento se enquadra na fase da criança, o que não quer dizer que o adulto não possa também aprender uma nova língua com certa facilidade.

Como pudemos observar, as questões apontadas ao longo de nossa discussão interferem no sucesso ou fracasso da aprendizagem de uma segunda língua. $\mathrm{Na}$ sequência, apresentamos os procedimentos empregados para a realização de nossa pesquisa, o que permitirá, posteriormente, confrontar, na análise, os pressupostos teóricos relacionados à aprendizagem de línguas e a realidade do ensino de língua portuguesa em Guiné-Bissau. 


\section{PROCEDIMENTOS METODOLÓGICOS}

Neste trabalho, desenvolvemos a reflexão sobre o ensino da língua portuguesa nas séries iniciais na Guiné-Bissau, analisando o perfil linguístico de amostra de estudantes guineenses, algumas características do material didático disponível e os métodos pedagógicos adotados para o ensino de português no país, além de outros aspectos envolvidos no processo de ensino de língua não materna.

\subsection{Entrevistas}

Para coleta dos dados, foi realizada entrevista com 54 interlocutores, todos de nacionalidade guineense, estudantes da Universidade Internacional da Lusofonia Afro-Brasileira (Unilab), localizada na cidade de Redenção, no estado do Ceará, com idades que variam de 20 a 30 anos. A entrevista foi dividida em duas partes: na primeira parte, aplicamos questionários a 50 entrevistados, divididos, proporcionalmente, em 25 mulheres e 25 homens; na segunda parte, realizamos a entrevista oral com 4 interlocutores, sendo também 2 homens e 2 mulheres. As entrevistas se desenvolveram, portanto, de duas formas: aplicação dos questionários escritos e de forma oral. As nossas questões de pesquisa através do formulário versaram sobre os seguintes objetivos específicos:

- Investigar qual a primeira língua desses estudantes guineenses;

- Saber com quantos anos esses estudantes guineenses aprenderam a língua portuguesa,

- Identificar o lugar onde aprenderam a língua portuguesa: em casa ou na escola,

- Saber como era processo de ensino de língua portuguesa, se havia aulas de conversação, comunicação oral, resultado de interação;

- Procurar saber se, durante as aulas do português, havia aulas destinadas ao estudo dos sons das palavras, ou estudo voltado para a pronúncia, como os sons são produzidos e a percepção dos sons em língua portuguesa;

- Identificar com que língua eles se comunicam com maior frequência com familiares e em casa;

- Verificar como é composto o perfil linguístico desses estudantes, isto é, quantas línguas falam;

- Saber se esses estudantes têm alguém na família que fala o português.

Nas quatro entrevistas orais, procuramos saber sobre as experiências no processo de ensino e aprendizagem das outras línguas, no caso, o francês e o inglês, 
e verificar o que haveria de diferente no ensino dessas línguas comparado ao ensino do português.

\subsection{Material didático analisado}

O material didático analisado para ensino da língua portuguesa é denominado PERIQUITO BETA, utilizado nas séries iniciais em quase todas as escolas do país. O material é elaborado na Guiné-Bissau e impresso em Dakar, tendo como autoras: Aurora Freitas de Barros, Maria do Carmo Mendes, Leontina Semedo Costa e, como coordenadora pedagógica, Monica Benoit. O material tem 88 páginas e é dividido em duas perspectivas do ensino da língua, a leitura e a escrita.

\section{RESULTADOS}

Em primeiro lugar, apresentamos o perfil linguístico dos estudantes guineenses entrevistados, apontando as frequências de respostas para cada uma das questões propostas no questionário; na sequência, apresentamos as características do material empregado no ensino de português em Guiné-Bissau, para, no final, elaborar um comparativo crítico entre o perfil dos estudantes e esse material, analisando sua (in) adequação, com base nos pressupostos teóricos pré-apresentados.

\subsection{Perfil linguístico dos guineenses entrevistados}

Dos 50 estudantes de ensino superior guineenses entrevistados, os dados apontam que 52\% têm como a primeira língua (L1/LM) as línguas étnicas, 46\% têm o guineense e $2 \%$ tem o wolof, a língua da República de Senegal, país vizinho da Guiné-Bissau. O português não aparece como a primeira língua ou língua materna (L1/LM) de nenhum desses informantes, ou seja, o guineense e as línguas étnicas constituem as línguas maternas desses entrevistados, conforme se pode ver no gráfico: 


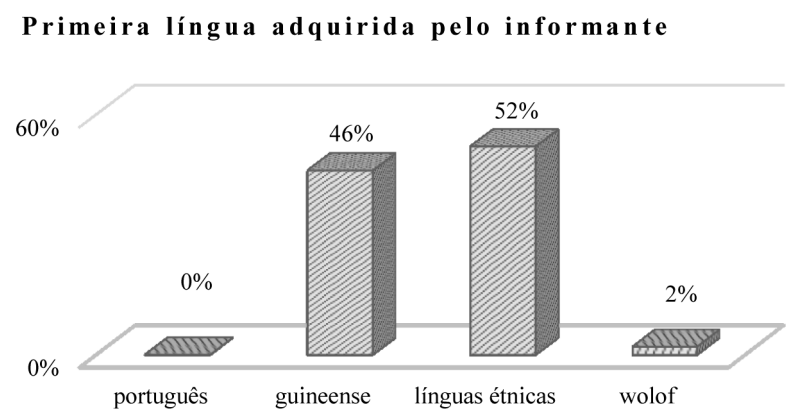

Gráfico 1. Primeira língua adquirida pelos estudantes guineenses

Os dados também mostram que a grande maioria desses informantes (98\%) aprendeu o português na escola, e apenas $2 \%$ (1 informante) em casa. Dessa forma, a escola constitui o espaço onde a língua portuguesa é adquirida, como se pode ver no gráfico que se segue.

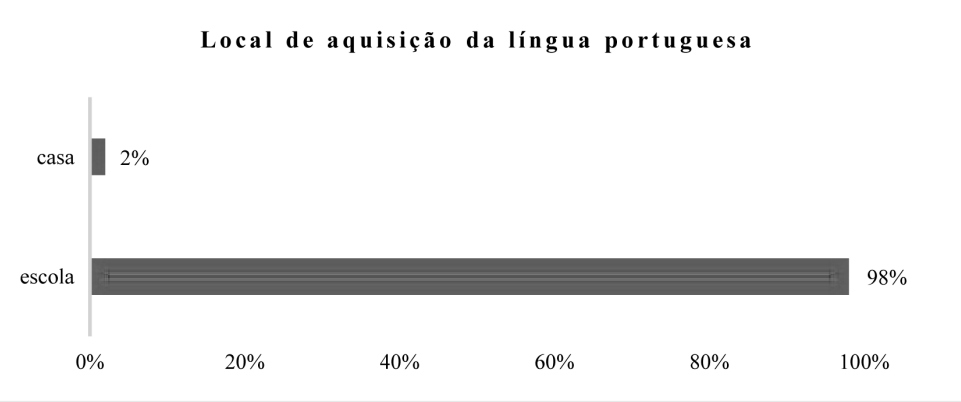

Gráfico 2. Local onde os informantes adquiriram a língua portuguesa

A hipótese por nós indicada no início deste trabalho foi confirmada, pois os dados comprovam que os guineenses, em sua grande maioria, adquirem o português somente na escola.

Em relação à idade de aquisição da língua, como era de se esperar pelos resultados dos gráficos anteriores, pudemos confirmar, que, em sua maioria, não ocorre nos primeiros anos de vida dos guineenses, como se pode observar na sequência. 


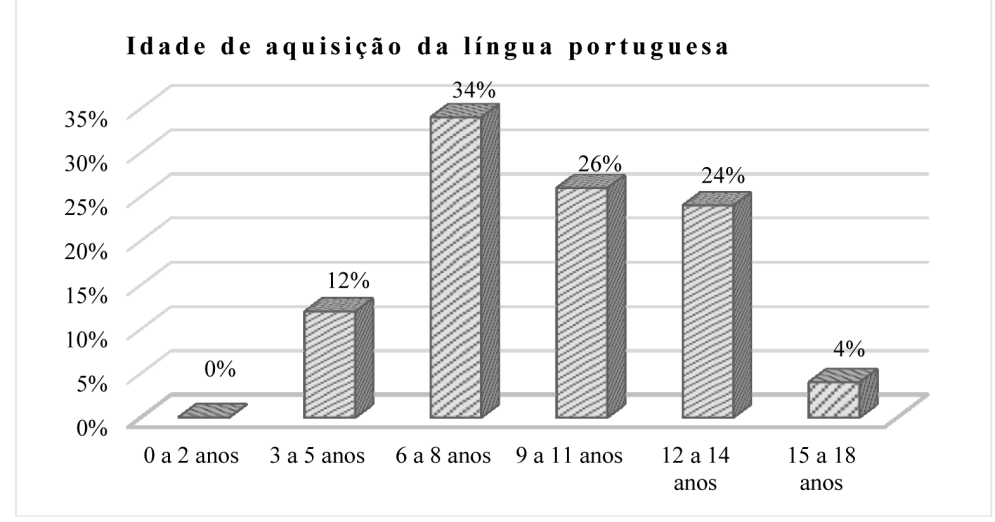

Gráfico 3. Idade com que os informantes adquiriram a língua portuguesa

É possível notar, pelos resultados do gráfico, que a maioria dos informantes teve contato com a língua portuguesa somente após os 6 anos de idade e mais da metade deles (54\%) apenas após os 9 anos. Merece destaque o fato de que nenhum dos informantes adquiriu a língua antes dos 3 anos.

Os dados apontam ainda que, além do português não se constituir em primeira língua (L1/LM) desses informantes, sendo aprendido na escola, na maioria dos casos, em idade superior aos 6 anos, também para maioria deles, no seio familiar, a comunicação é, predominantemente em guineense e nas línguas étnicas, pois 52\% comunicam-se em guineense e $48 \%$ nas línguas étnicas, como se pode ver no gráfico seguinte:

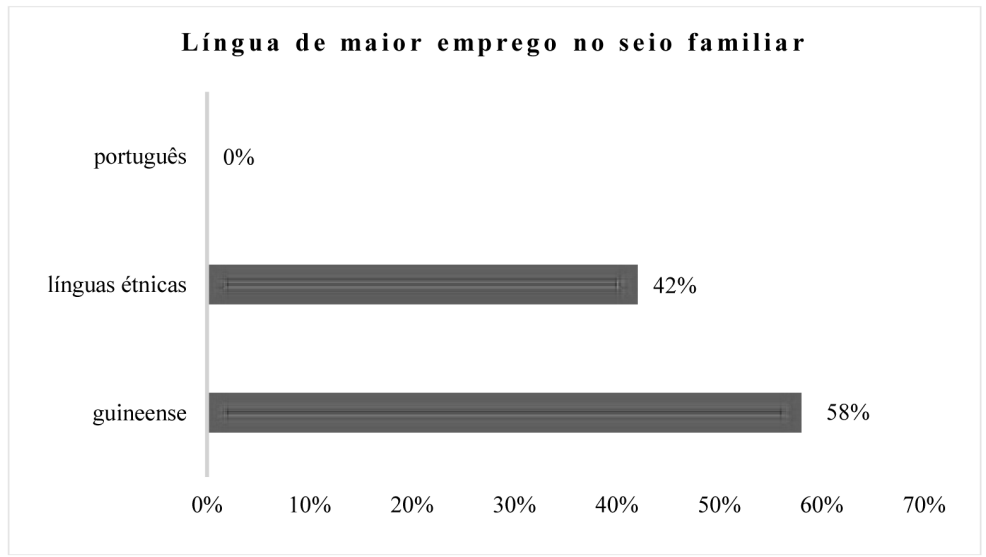

Gráfico 4. Língua com a qual os familiares se comunicam com o informante 
Como vemos, o português não é a língua de ampla comunicação no seio familiar. Fora do ambiente familiar, na sociedade mais ampla, a situação não é diferente, pois $96 \%$ dos informantes se comunicam em guineense, $2 \%$ nas línguas étnicas e apenas outros $2 \%$ se comunicam em português. Segue o gráfico que compila esses resultados:

\section{Língua falada com maior frequência}

mancanha; $2 \%$

português; $2 \%$

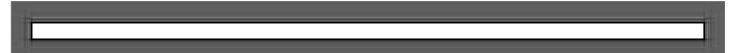

guineense; $96 \%$

$\begin{array}{llllll}0 \% & 20 \% & 40 \% & 60 \% & 80 \% & 100 \%\end{array}$

\section{Gráfico 5. A língua falada com mais frequência no dia a dia}

Além de a língua portuguesa não constituir a principal língua falada pelos estudantes fora do ambiente escolar, observamos um contexto multilíngue no país, pois, sem exceção, todos falam no mínimo duas línguas, o guineense e o português, conforme se comprova no gráfico a seguir.

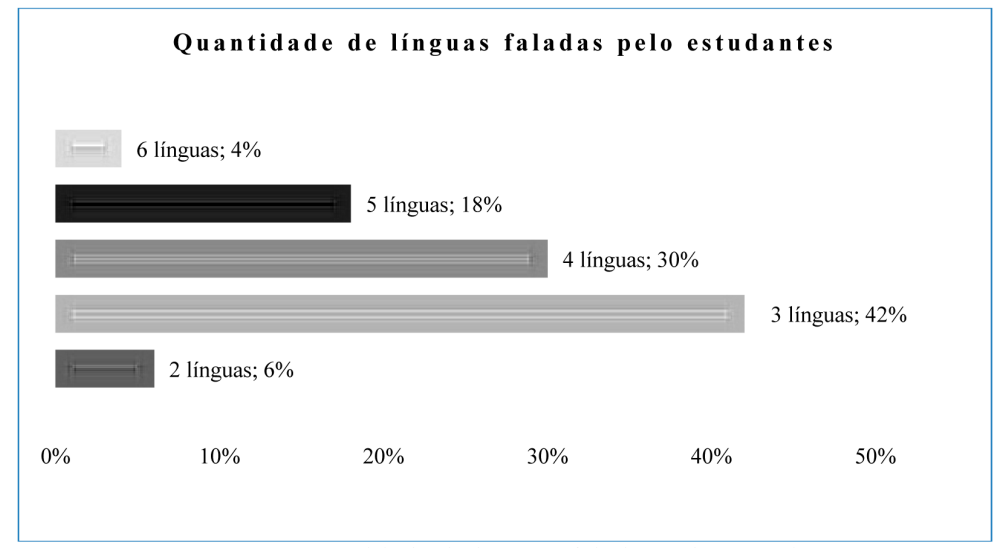

Gráfico 6. Quantidade de línguas faladas pelos estudantes

Como se pode observar, $42 \%$ dos estudantes pesquisados falam 3 línguas, $30 \%$ falam 4 línguas, $18 \%$ falam 5 línguas e $4 \%$ falam 6 línguas. Temos apenas $6 \%$ 
dos informantes se declarando bilíngues. Na sequência, o gráfico ilustrativo dessa configuração, com o levantamento de todas as línguas apontadas pelos estudantes.

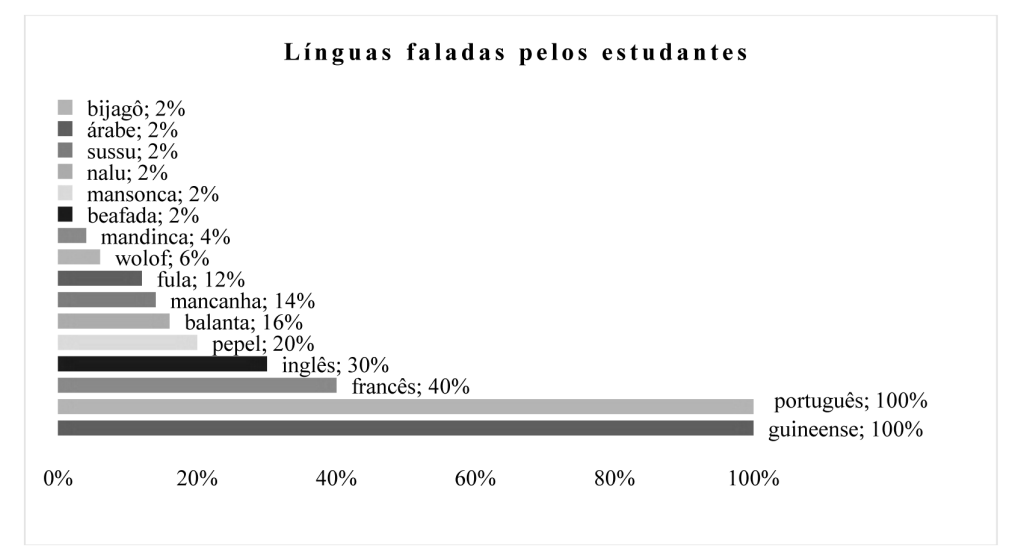

\section{Gráfico 7. Línguas faladas pelos estudantes guineenses}

Das línguas faladas pelos estudantes, destacam-se, além do português e do guineense ( $100 \%$ dos estudantes), o francês $(40 \%)$, o inglês $(30 \%)$, o pepel (ou papel) (20\%), o balanta (16\%), o mancanha (14\%), o fula (12\%), o wolof $(6 \%)$, o mandinca (ou mandinga) (4\%). As línguas beafada, mansonca, nalu, sussu, árabe e bijagó foram apontadas cada uma como faladas apenas por $2 \%$ dos informantes.

Os resultados da pesquisa apontam ainda, em relação ao perfil linguístico dos guineenses, que, em $44 \%$ das famílias dos informantes, somente o pai fala o português; em $36 \%$ das famílias, somente irmãos ou irmãs falam português; em $10 \%$, somente a mãe fala a língua. Há ainda $4 \%$ que declararam que somente tios ou tias falam português. Apenas $4 \%$ dos entrevistados apontaram que todos os membros da família falam o português. Um informante ( $2 \%$ da amostra) afirmou ser o único falante da língua portuguesa em casa. Na sequência, a compilação desses resultados: 


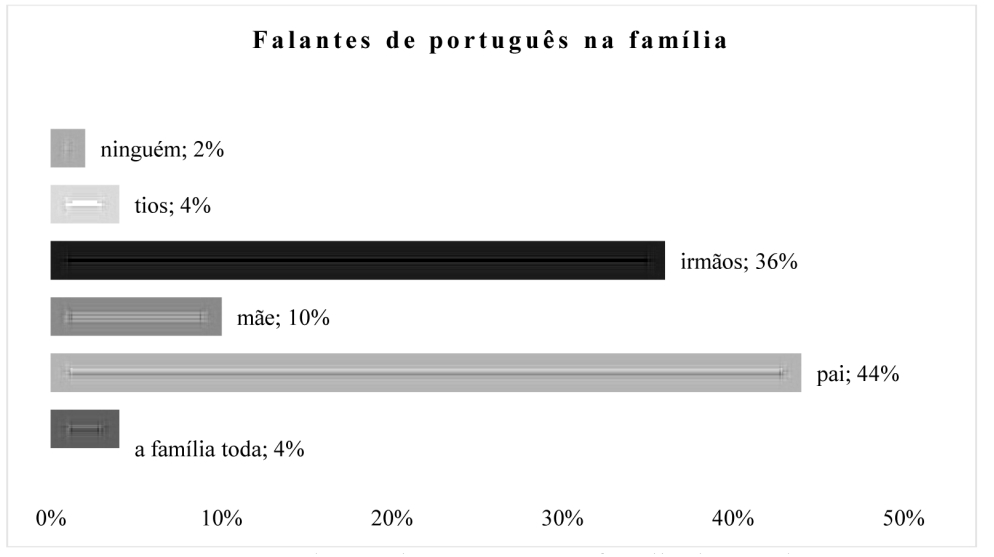

Gráfico 8. Falantes de português na família do estudante

Com base nos dados das entrevistas, vimos que o português não é a primeira língua adquirida ou assimilada por estudantes guineenses, pois eles têm como língua materna ou primeira língua uma das línguas étnicas ou o guineense, adquiridos ainda crianças, no meio familiar. Ou seja, são essas as línguas de primeiro contato, de convívio do dia a dia, de maior comunicação, de relação de afetividade e que marcam a identidade do povo guineense, tal como indicava previamente Embaló e Couto (2010).

O contato com o português se dá, pela primeira vez, no ambiente de sala de aula, na escola, já no início da chamada idade escolar, no mínimo aos seis anos de idade, para a maioria, não se constituindo na língua de convívio, não sendo falada com frequência, nem apontada como de uso diário, cabendo-lhe apenas as funções institucionais, caracterizando-se como língua de prestígio, dos escolarizados, das pessoas com certa ascensão social, mas não a língua de acesso para todos, já que somente $13 \%$ da população a emprega, conforme também já apontavam Embaló e Couto (2010).

Confrontando os resultados e os subsídios teóricos, podemos afirmar, com convicção, que a língua portuguesa não é LM dos guineenses. O período de aprendizagem do português não é considerado o mais propício para aquisição de uma nova língua, pois, segundo Nascimento e Santos (2013 apud SOUZA, 2015), a idade de maior facilidade para essa aprendizagem começaria na tenra infância, indo até os 5 anos de idade, intervalo de tempo no qual o desenvolvimento do cérebro é mais acelerado.

Contrapondo todos esses argumentos aos dados da entrevista, concluímos que a língua portuguesa, além de não ser LM dos guineenses, tem seu processo 
de aquisição fora do período ou da idade ideal, o que não impede, mas dificulta o processo de aprendizado da escrita e oralidade.

Os resultados também permitem afirmar que a língua portuguesa não é língua estrangeira, porque o termo "língua estrangeira", segundo Almeida Filho e Cunha (2007), aplica-se às línguas faladas fora das fronteiras do país, aprendidas apenas para estabelecer a comunicação com pessoas que vivem fora da comunidade de fala e não é usada na vida diária desse falante, não sendo indispensável para integração e relação com os demais membros da comunidade dos aprendentes.

Com base nessas constatações, na sequência, apresentamos breve análise do material didático para ensino de português em Guiné-Bissau, com o intuito de verificar se há adequação ao contexto linguístico verificado entre os estudantes guineenses.

\subsection{0 ensino de língua portuguesa em Guiné-Bissau}

Ao analisarmos o livro didático Periquito Beta, de Barros et al (1991), constatamos, preliminarmente, que o material não traz recursos sonoros, não apresentando textos acompanhados de quaisquer áudios como forma de auxiliar o aprendente na compreensão da escrita e na percepção e produção dos sons das palavras da língua em aprendizagem.

O material também não apresenta textos reais para o ensino, e nele predomina o emprego de sentenças soltas, descontextualizadas, sem sintagmas mais complexos que possam estabelecer diferentes relações entre as frases e as palavras, como se pode ver no trecho a seguir:

O Pelé papa a papaia.

A irmã Apili pila.

O papá põe o pau ao lume. A mama põe a saia.

O sapo pula para o pilão. (BARROS et al., 1991, p. 30)

Existe, no material, grande quantidade de sentenças e textos, nos quais se enfatizam mais as questões voltadas ao ensino do sistema, da estrutura e da função sintática da palavra, com foco somente nos elementos gramaticais. As propostas das atividades para o ensino da língua portuguesa estão voltadas, com maior ênfase, às atividades de cópia, de repetição e de escrita.

Ao analisarmos também como é proposto e elaborado o processo pedagógico do ensino da língua a partir do material didático, percebemos claramente que a preocupação maior recai em atividades e tarefas voltadas ao ensino da escrita e leitura. Em todo o material, não existem tarefas didáticas que focalizem o trabalho 
com os gêneros discursivos nos quais o estudante seja posto como falante, estimulando-o a usar a língua.

Em nenhum momento encontramos propostas de atividade ou tarefas voltadas à conversação, à prática da oralidade, ao uso da língua na sua forma real. A oralidade não é trabalhada nesse material do ensino do português, e isso contradiz Ferreira (2012), que defende o emprego de material didático contextualizado que leve em consideração o perfil linguístico, social e político dos falantes, inclusive considerando o fato de o aprendente, por exemplo, possuir outras línguas.

Conforme vimos, o material didático utilizado para o ensino da língua portuguesa na Guiné-Bissau é descontextualizado, não adequado para o ensino do português para esses estudantes. Essa incompatibilidade entre o material e as necessidades dos estudantes foi relatada pelos nossos interlocutores, pois, como apontam os resultados da pesquisa, $78 \%$ deles revelaram não ter, no ensino/aprendizagem de língua portuguesa, aulas de conversação, conforme consta no gráfico seguinte.

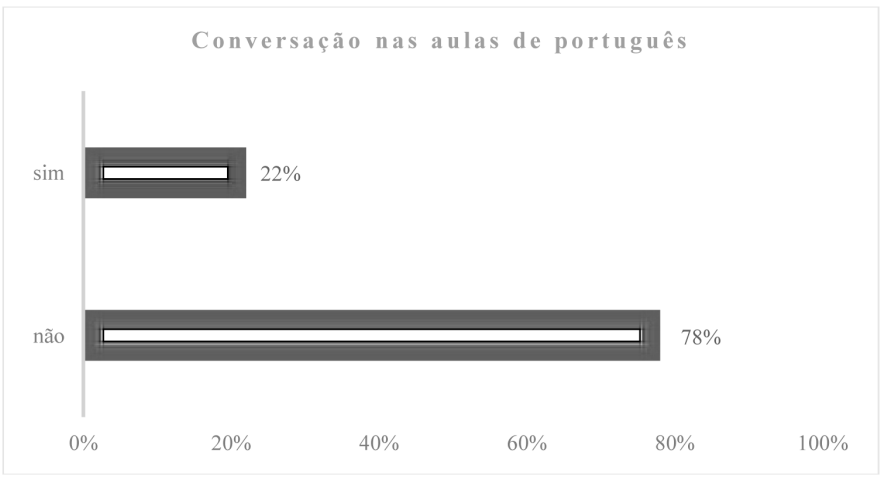

Gráfico 9: Conversação nas aulas de língua portuguesa dos estudantes guineenses

Da mesma forma, quando questionados sobre atividades que envolviam o estudo da percepção de produção sonora na língua alvo, o português, ou mesmo atividades com material sonoro, a quase totalidade dos estudantes apontou ausência do conteúdo, como se pode ver no gráfico que segue. 


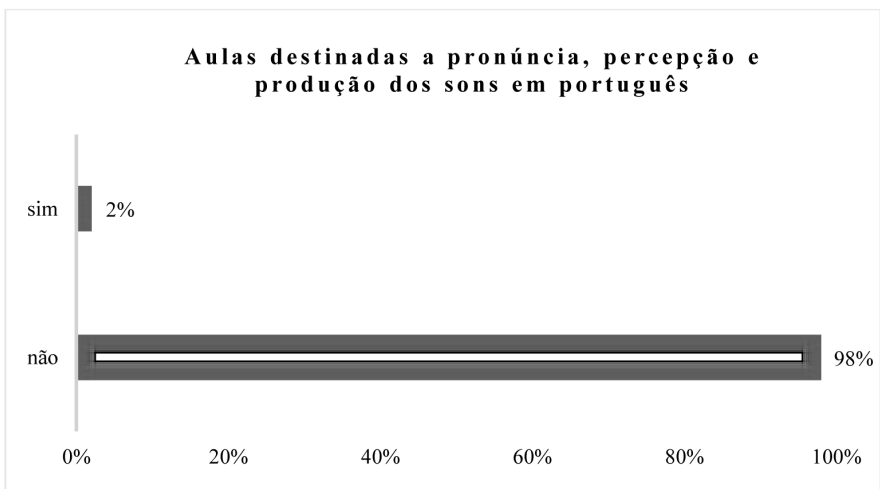

Gráfico 10: Aula de pronúncia, produção ou percepção dos sons em português

Com base no que foi exposto, apontamos que o material não atende aos requisitos mínimos de um material destinado ao ensino de português como segunda língua, sendo caracterizado pela ausência de atividades voltadas para a oralidade e, principalmente, para o contato do estudante com a língua em seu contexto de uso real, seja escrito ou oral.

As narrativas dos quatro informantes entrevistados oralmente, os quais passaram por um processo de aquisição de outra língua como L2, além do português, confirmam a discrepância entre os processos de ensino, ou seja, a relevância dos materiais sonoros no ensino da nova língua adquirida e a importância da interação ativa (comunicação/ conversação). Seguem as narrativas destes estudantes:

\section{Entrevistado 1:}

Eu levei mais tempo em estudar o português que o tempo que levei para aprender o inglês, mas se formos comparar o meu domínio de inglês... com relação ao português... eu julgo que tenho mais domínio em inglês com relação ao português. Tenho mais facilidade em expressar em inglês que em português. Imagina eu comecei a estudar o português desde primeira classe, na escola, e passaram 12 anos de primeira a décimo segundo ano, mas ainda tenho muitas dificuldades em português e o inglês apenas estudei em 2 anos, eu acho que a forma como nos ensinam o português é errado. $\mathrm{Na}$ escola de inglês, éramos obrigados a praticarem o inglês, falar mesmo, dialogo na turma, ver filme em inglês e interpretar na turma, falar do... você entendeu... sobre o filme. "Havia espaço para agente praticar a comunicação, aulas com áudio para ouvirmos a pronuncia das palavras, isto é, como sons são produzidos, mas isso nunca aconteceu na minha aula de português" (entrevistado-1, 2017, estudante de Curso de Letras -Lingua Portuguesa da Unilab). 
$\mathrm{Na}$ fala desse interlocutor, observa-se que, na escola de ensino de inglês onde estudou, a abordagem comunicativa era predominante, assim indispensável comentar, dialogar em inglês, como forma de treinamento. Havia instrumentos para que pudessem ouvir, perceber e aprender a pronúncia das palavras em inglês. O que não acontecia quando ele aprendia o português.

\section{Entrevistada 2:}

Eu acho que tenho mais dificuldades em aprender a língua portuguesa que qualquer língua...sério a língua portuguesa é cansativo... muito. Eu acho mais fácil... pelo menos pela minha experiência... é mais fácil aprender o francês que o português. Aprendi o francês com vídeos, sons. $\mathrm{Na}$ aula do português, os professores não faziam nada que pudesse ajudar o aluno aprender melhor a língua portuguesa. $\mathrm{O}$ ensino da língua portuguesa não deve ser apenas como uma disciplina. Mas ter a língua no seu uso. É importante que seja feita mudanças sobre a forma como nos ensinam a língua português. Tem que ser adotada as novas estratégias sobre o ensino da língua portuguesa, tipo adotar uso de áudios, aulas conversação, pois só comecei ter aulas de conversação na universidade, depois de 18 anos (entrevistada- 2, 2017, estudante do Curso de Enfermagem da Unilab).

Essa interlocutora aponta que o ensino e aprendizagem de português é mais difícil e cansativo, pois não se dava por meio da língua em uso. Para ela, os professores do português não tentavam elaborar atividades que contribuíssem no processo de aprendizagem da língua. A entrevistada, inclusive, recomenda que sejam adotadas outras estratégias que possam contribuir na melhoria do ensino do português, como o emprego de instrumentos sonoros, vídeos, áudios e que o português não seja ensinado como uma disciplina.

A outra interlocutora ouvida aponta que, após tantos anos de contato com a língua, deveria saber falar o português de maneira fluente, mas não é esse o caso e, se isso não acontece, é porque alguma coisa está errada. Segue a fala dessa entrevistada:

Entrevistada 3:

Ao estudar o inglês, os professores usaram uma metodologia que me deu mais facilidade para eu aprender melhor, pois ao aprender uma língua estrangeira você precisa começar pelo básico. Ao estudar o inglês comecei por vogais, pronúncia, como é que se pronuncia uma letra, tínhamos $\mathrm{CD}$ para aprender as pronúncias, o que não acontecia nas minhas aulas de português. Nas aulas de língua portuguesa só me ensinava as regras gramaticais, como os verbos são colocados. Não havia 
nem aulas com áudio para eu aprender as pronúncias das palavras. Na aula de inglês tínhamos aulas de conversação, mas nas aulas de portuguê não existia nada disso. Se convertêssemos o tempo e o período que durei em aprender o português, esse tempo fosse o tempo para eu aprender o inglês eu seria uma britânica, isto eu falaria o inglês fluentemente (entrevistada - 3,2017, estudante de curso da Ciências Biológicas da Unilab).

A metodologia usada quando aprendia o inglês, segundo a entrevistada, ajudou bastante, pois, ao ensinar uma língua nova, partiu-se do básico, do mais simples para o mais complexo, utilizando ferramentas que auxiliassem os alunos na compreensão dos conteúdos. O problema no aprendendizado do português se deveu, segundo ela, aos precários procedimentos metodológicos do ensino da língua. Abaixo a fala do quarto e último entrevistado:

\section{Entrevistado 4:}

Eu aprendi o francês quase em oito meses e já com um ano comecei a falar fluentemente [...] durante as minhas aulas de francês havia muitos materiais utilizados, livros variáveis contextualizados por cada nível, havia caixa de som, rádios, os professores mostravam a escrita e áudios para que os alunos aprendentes possam acompanhar. Os professores trabalhavam a oralidade e a escrita ao mesmo tempo. Em cada sexta-feira, havia o debate, momento em que cada pessoa preparava os seus argumentos para poder expor dentro da sala. E todas as pessoas que tinham as dificuldades de expressar começavam a desenvolver a sua capacidade oral e isso era tão fantástica. Se a metodologia que foi usado para eu aprender o francês... se fosse a mesma utilizada para eu aprender o português eu teria uma fluência mais que qualquer nativo português porque levei todo o tempo estudando o português[...] as perguntas em português eram diretas, como o que é adjetivo e o que é substantivo. Era só dizer o que significava isso, e nem o professor interessava em saber se o aluno sabia falar ou não, saber usar a língua. Em curto tempo aprendi o francês e falo fluentemente. (entrevistado -4 - estudante de curso de Engenharia da Energias da Unilab, 2017).

O entrevistado julga que teve grande avanço no aprendizado do francês porque havia muitos materiais disponíveis para o ensino e, desses materiais, livros variáveis e contextualizados que levavam em consideração o nível dos aprendentes, o perfil linguístico, além de haver rádios, caixa de som, para produção e percepção dos sons, e os professores, que trabalhavam a oralidade e escrita ao mesmo tempo. $\mathrm{O}$ entrevistado menciona ainda o emprego do gênero debate, no qual os alunos tinham que se expressar na língua alvo. 
Dessa forma, a incompatibilidade do material didático para o ensino de língua portuguesa na Guiné-Bissau é confirmada também nas narrativas, que apontam distanciamento das aulas em relação à realidade linguística dos estudantes e apontam para a importância de uma abordagem comunicativa como forma de viabilizar o ensino e aprendizagem mais eficaz.

\section{CONSIDERAÇÕES FINAIS}

No desenrolar da pesquisa, com base na discussão a respeito do perfil linguístico dos estudantes guineenses, dos procedimentos metodológicos para o ensino do português, a partir das características do material didático analisado, e das entrevistas orais, constatamos várias incompatibilidades nesse processo. A inadequação no ensino de língua portuguesa na Guiné-Bissau é marcada por diversos fatores, sejam eles internos ou externos.

Dessas inadequações, destaca-se o emprego de material didático que não considera o perfil linguístico ou realidade linguística dos estudantes guineenses, pois o material disponível para o ensino de português no contexto guineense apresenta características típicas de quem tem o português como língua materna, diferentemente do que aponta a análise do perfil dos estudantes guineenses.

Além do uso de material descontextualizado, que não leva em consideração a realidade guineense, os estudantes aprendem o português em diferentes idades, muitas vezes já na adolescência ou fase adulta, em idade posterior à apontada por alguns especialistas da linguagem e da neurociência como mais adequada. Assim, soma-se ao material didático inadequado, o contato, por vezes em fase adulta, com a língua, o que torna ainda mais complexa a aprendizagem, se considerados os procedimentos metodológicos adotados, com o português ensinado como uma disciplina normativa, com foco na gramática, na estrutura da língua, no sistema abstrato, na nomenclatura dos elementos gramaticais, em frases soltas, sem conexão e contextualização, e com ausência de textos reais.

A abordagem comunicativa, que a despeito de limitações poderia contribuir no processo de ensino, não é empregada, e as propostas de atividades para ensino da língua portuguesa estão voltadas à cópia e à repetição, como forma de fixar as regras da gramática normativa, e os estudantes não são incentivados a desenvolver a capacidade de oralidade, através do ensino da conversação.

Todas essas questões vêm gerando, a longo prazo, dificuldades na aquisição da escrita e oralidade em língua portuguesa pelos estudantes guineenses, como se pode constatar pelo depoimento dos entrevistados. 
Seria importante uma reestruturação do material, com prioridade para as atividades que partem do o uso real da língua, nos diferentes contextos de dentro e de fora das salas de aulas.

Não se pode empregar o mesmo modelo do material didático feito para um falante que tem a língua portuguesa como língua materna, principalmente, para um contexto linguístico complexo (de multilinguismo) como o da Guiné-Bissau.

É relevante alertar que a elaboração do material didático, assim como o ensino da língua portuguesa na Guiné-Bissau, deve ser pensado respeitando e aceitando a realidade da língua no país. Os professores, que vão trabalhar com o material precisam ter uma formação, ou uma reciclagem de capacitação, para que possam empregar de forma plena e eficaz o seu conteúdo.

O ensino da língua portuguesa (ou de qualquer outra língua) como L2 ultrapassa o simples conteúdo linguístico e devem ser levadas em consideração outras habilidades do estudante. As atividades a serem desenvolvidas na sala de aula devem contribuir em estimular o aluno à prática da oralidade, e não meramente à leitura e escrita.

Reconhecemos que todas essas indicações e propostas, como, por exemplo, o trabalho de reelaboração do material didático, com atendimento de todas as demandas, e o ensino contextualizado, com professores qualificados, não é tarefa fácil - principalmente, para um país como a Guiné-Bissau, que tem sofrido muitos sobressaltos políticos nos últimos anos, e que, por enquanto, depara-se com dificuldades econômicas -, contudo, contribuiria sobremaneira para a gradativa melhoria na proficiência em língua portuguesa dos estudantes guineenses.

\section{$\overline{\text { REFERÊNCIAS }}$}

ALMEIDA FILHO, J. C. P. (2005). O ensino de português como língua não-materna: concepções e contextos de ensino. Museu da Língua Portuguesa. Disponível em: $<\underline{\text { http: } / /}$ museudalinguaportuguesa.org.br/wp-content/uploads/2017/09/ENSINO-COMOLINGUA-NAO-MATERNA.pdf > . Acesso em: 12 abr. 2016.

ALVES, L. R. M. (2012). O desenvolvimento de destrezas de escrita em estudantes de Português Lingua Estrangeira: Componentes lexicais, gramaticais, gráficas e pragmáticas. Relatório de estágio mestrado em português língua não materna: português língua estrangeira e português língua segunda. Universidade de Minho, Instituto de Letras e Ciências Humanas, Braga, 66 p. Disponível em: <http://repositorium.sdum.uminho.pt/ bitstream/1822/24034/1/Liliana\%20Raquel\%20M onteiro\%20Alves.pdf $>$. Acesso em: 11 abr. 2017. 
ANTUNES, I. (2003). Aula de português: encontro e interação. São Paulo: Parábola Editorial.

BASSO, R. M. GONÇALVES, R. T. (2014). História concisa da língua portuguesa. Petrópolis: Vozes.

BARROS, A. F.; MENDES, M. C.; COSTA, L. S.; BENOIT, M. Periquito Beta. Editora Escolar: Dakar, 1991.

BENTO, C. I. S. (2013). Aquisição de Português Lingua Não Materna - o conjuntivo na interlíngua de falantes nativos de neerlandês. Dissertação de Mestrado em Ensino de Português Língua Segunda e Língua Estrangeira, Faculdade de Ciências e Humanidades, Universidade Nova, Lisboa, 154 p.

BENZINHO, J.; ROSA, M. (2015). Guia Turístico: à descoberta da Guiné-Bissau. Coimbra: Ediliber.

CARVALHO, G. L. (2011). Unidades fraseológicas no ensino de português língua estrangeira: os últimos serão os primeiros. Dissertação de Mestrado, Universidade Federal do Ceará. Fortaleza, 126 p.

COUTO, H. H.; EMBALÓ, F. (2010). Literatura, Língua e Cultura na Guiné-Bissau: Um país de CPLP. Revista Brasileira de Estudos Crioulos e Similares, Papia, n. 20, Brasília, $256 \mathrm{p}$

CRUZ, A. V. (2013). Abordagem comunicativa-enfoque na competência oral na língua segunda: caso da Guiné-Bissau. Dissertação de Mestrado, Faculdade de Letras da Universidade de Porto, 252p. Disponível em: < https://repositorio-aberto.up.pt/ handle/10216/70677>. Acesso em: 10 mai. 2016.

ALMEIDA FILHO, J. C. P. de; CUNHA, M. J. C. (2007). Projetos Iniciais em Português para Falantes de Outras Linguas. Brasília: Ed. da UnB.

FERREIRA, L. L. (2012). Ensino de Português L2 e Produção de Material DidáticoPedagógico: Formação continuada de professores Xavante. Visitas Guiadas. GIL, B. D.; AMADO, R. S. (org.). Reflexões sobre o ensino de português para falantes de outras línguas. São Paulo: Paulistana, p.49-54.

FERREIRA, M. (1988). Que futuro para a língua portuguesa em África? Lisboa- Portugal: ALAC AFRICA.

GUIMARÃES, E. (2007). Conceitos linguísticos: língua franca. Enciclopédia das línguas no Brasil. Disponível em: < http://www.labeurb.unicamp.br >. Acesso em: 5 abr. 2014. 
GUINÉ-BISSAU INEC (INSTITUTO NACIONAL DE ESTATÍSTICA E CENSOS) (2014). Guiné-Bissau em Números - Bissau. Disponível em: < http://www.stat-guinebissau. com/publicacao/GB_Numerofinal_Publica\%C3\%A7\%C3\%A3o1.pdf $>$. Acesso em 3 de abr. 2017.

LEIRIA, I. (1999). Português língua segunda e língua estrangeira: investigação e ensino, Departamento de Linguística Geral e Românica da Faculdade de Letras da Universidade de Lisboa, $1^{\mathrm{a}}$ congresso de português língua não materna, Pacoas, Lisboa, p. 1-11.

MENDES, E. (2011). Diálogos internacionais: ensino e formação em português língua estrangeira, Campinas, SP: Pontes Editores.

MOREIRA, D. (2006). Políticas públicas de alfabetização de massa na Guiné- Bissau. Mestrado em Linguística Aplicada, Universidade do Estado do Rio de Janeiro, Rio de Janeiro, 167 p.

PEIXOTO, C. M. M.; CARIOCA, C. R. (2012). As Representações linguísticas dos acadêmicos guineenses: uma reflexão sobre o estatuto da língua portuguesa fundamentada no corpus do PROFALA. Congresso Internacional de Dialetologia e Sociolinguística, Belém. Anais... Belém: UFPA, p. 438-450.

PEIXOTO, C. M. M. (2007). Análise da Proposta de Planejamento de aulas de leitura do material Didático do Projovem. Mestrado em Linguística Aplicada. Universidade Federal do Ceará. Fortaleza, 141 p.

PETTER, M. (2015). Introdução à Linguística Africana. São Paulo: Contexto.

SCHOFFEN, J. R. (2012). Português como língua adicional: reflexões para a prática docente. Porte Alegre: Bem Brasil.

SELLAN, A. R. B. (2012). Língua e cultura no ensino-aprendizagem do português Brasileiro: Visitas Guiadas. GIL, B. D.; AMADO, R. S. (Org.). Reflexões sobre o ensino de português para falantes de outras línguas. São Paulo: Paulistana, p.27-32.

SEVERO, C. G. (2013) Política(s) linguística(s) e questão de poder. Alfa, São Paulo, 57 (2), p. 451-473

SOUTO, M.; ALÉM, V. L.; GONZALES, A. O. F. (2014). Conceitos de língua estrangeira, língua segunda, língua adicional, língua de herança, língua franca e língua transnacional, Anais da IX JNLFLP. Rio de Janeiro: CiFEFiL, set./dez, p. 890-900. Disponível em: http://www.filologia.org.br/revista/60sup/070.pdf. Acesso em: 18 de maio de 2017. 
SOUZA, A. S. (2015). O processo de aquisição de um segundo idioma em crianças e adultos. Estação Científica - Juiz de Fora, $n^{\circ}$ 14, julho - dezembro. Disponível em: < http://portal. estacio.br/docs\%5Crevista_estacao_cientifica/08-14.pdf $>$.Acesso em 07 de abril de 2017.

SPINASSÉ, K. P. (2006). Os conceitos língua materna, segunda língua e língua estrangeira e os falantes de línguas alóctones minoritárias no sul do Brasil. Revista Contingentia, v. 1, nov. 2006, p. 1-10. Disponível em: < http://www.lume.ufrgs.br/bitstream/ handle/10183/20578/000639062.pdf? sequence=1>. Acesso em: 17 mar. 2017.

TAVANI, G. (1975). Problemas da expressão linguístico-literária nos países africanos de independência recente. Estudos italianos em Portugal, n. 38/39. Lisboa: Instituto Italiano de Cultura. Disponível em: < http://memoria-africa.ua.pt/Catalog/ShowRecord. aspx? $\mathrm{MFN}=41109>$. Acesso em: 3 abr. 2017.

TEIXEIRA, M. (2012). A produção textual em livros didáticos de português língua estrangeira/ português língua segunda. GIL, B. D.; AMADO, R. S. (Org.). Reflexões sobre o ensino de português para falantes de outras línguas. São Paulo: Paulistana, p. 55-61.

UETI, L. S. (2012). O gênero carta de pedido de conselhos nos LDS de PFOL. GIL, B. D.; AMADO, R. S. (org.). Reflexões sobre o ensino de português para falantes de outras línguas. São Paulo: Paulistana, p. 13-20.

Recebido: 12/12/2018

Aceito: 7/02/2019

Publicado: 29/03/2019 